\title{
The Harvard Law Review AND THE IROQUOIS INFLUENCE THESIS
}

\author{
Erik M. Jensen* \\ Case Western Reserve University
}

\begin{abstract}
In a recent Developments in the Law chapter on the Indian Civil Rights Act, authors and editors at the Harvard Law Review seemed to take seriously the so-called "Iroquois influence thesis," the idea that basic principles of the American government were derived from American Indian nations, in particular the Iroquois Confederacy. Although the influence thesis has acquired a life of its own, being taught in some of America's elementary and secondary schools, it is nonsense. (One of the sources cited in support of this made-up history is a congressional resolution, as if Congress has some special, historical expertise.) Nothing in American Indian law and policy should depend on the influence thesis, and it is unfortunate that a prominent law review has given it credence. This article explains how the Harvard folks were misguided and why the influence thesis should be interred.
\end{abstract}

\section{CONTENTS}

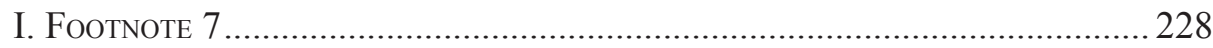

A. The Franklin Letter ......................................................................... 228

B. The Concurrent Resolution .............................................................. 232

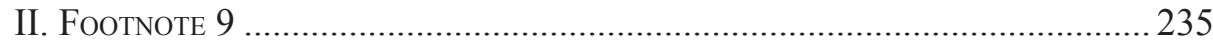

III. A Few Additional Thoughts on the Influence Thesis .......................... 237

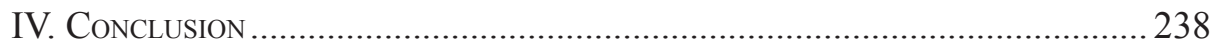

Appendix: The Incongruity at the Core of the Developments Chapter ...... 239

* Coleman P. Burke Professor Emeritus of Law, Case Western Reserve University. The author thanks Lisa Peters, of the CWRU Law Library, for her invaluable assistance. 
A recent Developments in the Law chapter in the Harvard Law Review, "ICRA Reconsidered: New Interpretations of Familiar Rights," discussed what the Indian Civil Rights $\mathrm{Act}^{2}$ and its nearly fifty-year history tell us about the relationship between American Indian tribal governments (as varied as they are) and the government of the United States. It's noncontroversial to emphasize, as the chapter did, the tension that has existed throughout American history between those two sets of governments. And ICRA itself is evidence of that discomfort, with Congress seeking to impose American constitutional values, including much of the Bill of Rights, on the American Indian nations - for arguably good reasons, but an intrusion into tribal sovereignty nonetheless.

Recognizing the perhaps inevitable "tension between promoting tribal sovereignty and protecting individual rights"3 - something has to give - the Developments chapter came down on the side of letting tribes, which are sovereigns, after all, make their own decisions on ICRA matters, even in habeas cases. That recommendation isn't self-evidently right, however, when tribal members are claiming that their civil rights were violated by their own tribal governments. Should government officials really have the final say about the legality of their own behavior? In addition, Congress singled out habeas cases for special treatment under ICRA, with review available in "a court of the United States." In an appendix, I've set out a few thoughts on the merits of the Developments chapter's substantive arguments.

My purpose in the body of this article is not to challenge the overall argument of the Developments chapter, however. It's to emphasize something even more important (important because scholarly failings matter): to demonstrate that some of the authority cited in that chapter is embarrassing. Why in the world did the authors cite, and the Harvard Law Review editors permit the citation of, documents that support, or are claimed to support, the "influence thesis"? That's the increasingly pervasive, but silly, idea that the governing principles of the United States, including those in the U.S. Constitution, were influenced - heavily influenced - by American Indian nations, particularly the Iroquois Confederacy. ${ }^{5}$

The influence thesis is wishful thinking, nothing more ${ }^{6}$-it's supposed to

129 Harv. L. Rev. 1709 (2016) [hereinafter Developments].

Pub. L. No. 90-284, tit. II, 82 Stat. 73,77 (1968) (codified at 25 U.S.C. §§ 1301-1304). Developments, at 1709 .

$4 \quad$ See 25 U.S.C. $\S 1303$ (providing that "[t]he privilege of the writ of habeas corpus shall be available to any person, in a court of the United States, to test the legality of his detention by order of an Indian tribe," but making no other mention of the possibility of federal court review of an alleged tribal violation of ICRA).

5 Some of the fundamental works associated with the spread of this idea in the last 30-40 years are Bruce E. Johansen, Forgotten Founders: How the American Indian Helped Shape Democracy (1982); Jack Weatherford, Indian Givers: How the Indians of the Americas Transformed the World 133 (1988) (chapter entitled "The Indian Founding Fathers"); Donald A. Grinde, Jr. \& Bruce E. Johansen, Exemplar of Liberty: Native America AND the Evolution of Democracy (1991).

6 The influence thesis has nevertheless been incorporated into the curricula of American school systems and some college programs as well. See Bruce E. Johansen, Reaching the Grassroots: The World-Wide Diffusion of Iroquois Democratic Traditions (2002) (providing evidence, with approval, of the spread of the influence thesis in schools), available at http://www.ratical.org/many_worlds/6Nations/grassroots.html; Iroquois Confederacy and the US Constitution (curricular unit at Portland State University), available at http://www.iroquoisdemocracy.pdx.edu/. But see Samuel B. Payne, Jr., The Iroquois League, the Articles of Confederation, and the Constitution, 53 WM. \& MARY Q. 605, 606-07 (1996) (critically discussing the spread of the thesis in schools). 
make us feel good - and, based as it is on little or no evidence, it should disappear from scholarly discourse. It certainly shouldn't be propped up by citations in the Harvard Law Review. As a "scholarly" doctrine, the thesis is generally the product of a few writers citing each other back and forth, and wrenching founding-era (and other) quotations out of context, in support of otherwise unsupportable positions. ${ }^{7}$ Members of Congress have done the quotation-wrenching as well, ${ }^{8}$ and some tribal officials have wrongheadedly jumped on the influence-thesis bandwagon. ${ }^{9}$

The thesis is dumb, but it also should have been irrelevant to the argument advanced in the Developments chapter. (If that argument does depend on such questionable authority, it's grounded in quicksand.) In support of the proposition that tribal governments deserve deference in applying ICRA, the authors argued that the American colonists mindlessly resisted the idea that the American Indian nations had laws and governments worth paying attention to, ${ }^{10}$ and we continue to resist today. Fair enough (perhaps), but the influence thesis doesn't support those points. The Developments authors seem to have been of two minds - that the American colonists didn't value tribal laws and governments, yet the founders appropriated Indian political ideas to use in the Constitution. Those two propositions can't both be right.

To be sure, the Developments authors didn't explicitly say they were endorsing the influence thesis. But, if they weren't, why cite to material that (1) overstates the tribal influence on the founding and (2) is, or should be, irrelevant to the argument being advanced? What's included in footnotes matters, as editors and associates at the Bluebook's home surely know, and these citations seem to have been motivated by political correctness, not scholarly merit. ${ }^{11}$

In the first two parts of the article I examine in some detail a couple of the suspect footnotes. (That sounds excruciatingly boring, I know, but it's no more so than any other law review subject.) In part III, I add further thoughts about why the influence thesis should be summarily rejected. Finally, in the conclusion, I note that the influence thesis has potentially negative effects on the American government's conception of, and policy toward, American Indian nations - another reason the thesis should be interred, not celebrated.

See, e.g., infra note 40 (noting academic historian's presentation to congressional committee of misleading quotation from George Washington); infra note 49 (noting independent historian's misleading statement of legislative history).

$8 \quad$ See infra text accompanying note 35 .

9 See infra notes $64 \& 71$ and accompanying text. The officials apparently see a tribal benefit from the thesis, but there's no long-term benefit in supporting an indefensible thesis.

10 See, e.g., Developments, at 1711 ("[T] $]$ he governments that arrived in North America searched for the particular forms of law and government with which they were familiar and, finding them lacking, sought to impose civilization and order (of their own style) upon tribes.") (footnotes omitted); id. at 1710 ("European and American distrust of, or disinterest [sic] in, Indian tribal affairs led them to apply their laws and philosophies to the exclusion of Indians' own views in those areas.") (footnote omitted).

11 Or maybe everyone was too busy writing Supreme Court clerkship applications to do routine Review work. 


\section{FoOTNOTE 7}

Footnote 7 in the Developments chapter was dropped from a clause that reads, "Indians had successfully designed and developed advanced governments and laws to protect the rights of their peoples long before the federal government thought to suggest these institutions to tribes." 12 That's true, up to a point, I suppose. I'm not sure how much traditional tribal governments were instituted to protect individual rights against overreaching by those governments, or the extent to which we should treat customs and practices as "advanced laws." But for the sake of argument I'll accept that textual statement. ${ }^{13}$

But footnote 7 went far beyond the idea that the tribes had governments and laws, as of course they did. The authors cited and quoted from two sources that are among the usual suspects in supporting the influence thesis - a 1751 (or perhaps 1750) letter from Benjamin Franklin to James Parker and a 1988 Concurrent Resolution passed by Congress. Neither citation provides support for much of anything worthwhile - the Franklin letter because the quoted language gives a misleading idea of Franklin's meaning and the Concurrent Resolution because it's nonsense on stilts promulgated by a political body, not a group of scholars.

\section{A. THE FRANKLIN LETTER}

In the letter to Parker, according to footnote 7, Franklin "observed ... that the success of the Iroquois Confederacy, which 'has subsisted ages, and appears indissoluble,' demonstrated the feasibility of union for the colonies." 14 That statement supposedly supported the idea that, "[i]n fact, tribal governments had an impact on the development of the federal government." 15

Read in isolation, that latter statement is unobjectionable. Obviously the Constitution was affected, in that Indians and Indian tribes are both mentioned in that document. ${ }^{16}$ (We don't need a quotation from Benjamin Franklin to find

12 Developments, at 1711 (footnote omitted).

13 Whether the founders would have accepted it is doubtful. See, e.g., Letter from Thomas Jefferson to Edward Carrington (Jan. 16, 1787), reprinted in 11 THE PAPERS OF ThOMAS JefFerson 48, 49 (Julian P. Boyd ed., 1955) ("I am convinced that these societies (as the Indians) which live without government enjoy in their general mass an infinitely greater degree of happiness than those who live under European governments.") (emphasis added). To John Locke, after all, America, as occupied by the indigenous peoples, had been the prime example of the state of nature. See also John Adams, A Defence of the Constitutions of Government of the United States of America xv, 118 (1787; Da Capo reprint 1971) (referring to the "rudest tribes of savages in North America" and "the savages of North or South America"). (Full disclosure: Neither Jefferson nor Adams was a delegate to the Constitutional Convention.)

14 Developments, at 1710 n.7 (citing and quoting Letter from Benjamin Franklin to James Parker (Mar. 20, 1750/51) [hereinafter Franklin Letter], reprinted in 4 THE PAPERS OF Benjamin FrankLin 117, 120 (Leonard W. Labaree ed., 1961)).

15 Developments, at 1710 n.7.

16 See U.S. ConsT. art. I, § 8, cl. 3 (giving Congress the power "To regulate Commerce with foreign Nations, and among the several States, and with the Indian tribes"); id., art. I, § 2, 
those constitutional provisions.) Furthermore, the founders, who were students of government, prided themselves on their study of other regimes, so it's not surprising that many were interested in the governance (or, as some thought, the lack of governance) of American Indian nations..$^{17}$ (In that respect, ancient Greece and the Roman Empire also had "an impact on the development of the federal government.") And of course the colonists and the tribes had contact, but those meetings (or confrontations) typically didn't involve discussions of political philosophy. ${ }^{18}$

The gulf between general statements about colonist-tribal relationships and the purported influence of the Iroquois Confederacy is enormous. In fact, the contact between colonists and Indians often wasn't friendly, which by itself should call into question the influence thesis. And a closer look at the Franklin letter demonstrates that Franklin didn't mean what footnote 7 said he meant.

The purpose of the letter was to advise Parker, a printer and long-time Franklin friend, who had asked Franklin and others for guidance about publishing a pamphlet apparently prepared by Archibald Kennedy, The Importance of Gaining and Preserving the Friendship of the Indians to the British Interest Considered, ${ }^{19}$ also cited in footnote 7. Although neither Kennedy nor Franklin was identified in the pamphlet, ${ }^{20}$ the pamphlet included what is assumed to be Franklin's response to Parker's inquiry about the merits of the document. The letter is introduced in the pamphlet as follows: "The Author of the foregoing ESSAY, having desired the Printer to communicate the Manuscript to some of the most judicious of his Friends, it produced the following LETTER from one of them: The publishing whereof, we think, needs no other Apology, viz." ${ }^{21}$ (Franklin had recommended publishing the pamphlet. ${ }^{22}$ )

In the first paragraph of the letter, Franklin wrote:

I have, as you desire, read the Manuscript you sent me; and of Opinion $[s i c]$, with [Kennedy], that securing the Friendship of the Indians is of the greatest Consequence to these colonies; and that the surest Means of doing it, are, to regulate the Indian Trade, so as to convince them, by

cl. 3 ("excluding Indians not taxed" from the census count used to apportion representatives and direct taxes).

17 See supra note 13 (noting that, for some from the founding generation, the existence of tribal governments and laws wasn't obvious).

18 See Erik M. Jensen, The Imaginary Connection Between the Great Law of Peace and the United States Constitution: A Reply to Professor Schaaf, 15 Am. Indian L. Rev. 295, 303 (1991) (discussing founders' dealings with Indians that went beyond land speculation) (responding to Gregory Schaaf, From the Great Law of Peace to the Constitution of the United States: A Revision of America's Democratic Roots, 14 Am. Indian L. Rev. 323 (1989)).

19 See Archibald Kennedy, The Importance of Gaining and Preserving the Friendship of the Indians to the British Interest Considered (1752), available at http://quod.lib. umich.edu/e/evans/N05302.0001.001/1:4?rgn=div1; view=fulltext.

20 See Elizabeth Tooker, The United States Constitution and the Iroquois League, 35 EтHNOHISTORY 305, 327 (1988) (noting that Franklin wasn't identified as the letter's author for a century, which suggests that we should be skeptical about overstating its influence during the founding period); Editor's Biographical Note, Franklin Letter, supra note 14, at 117 (noting attribution of the letter to Franklin by Edward Eggleston in a note to John Bigelow, who was preparing an edition of Franklin's work that was published in 1887-88).

21 KenNedy, supra note 19, at 28-29.

22 See Franklin Letter, supra note 14, at 121. 
Experience, that they may have the best and cheapest Goods, and the fairest Dealing from the English; and to unite the several Governments, so as to form a Strength that the Indians may depend on for Protection, in Case of a Rupture with the French; or apprehend great Danger from, if they should break with us. ${ }^{23}$

As the last clause confirms, Franklin didn't think that the relationship between colonists and Indian nations was necessarily friendly. Friendship wasn't a given; it needed to be "secur[ed]." And the title of the Kennedy pamphlet also suggested that it was necessary to "gain" the friendship of the Indians. ${ }^{24}$

The tension between tribes and colonists didn't disappear during the time between the publication of the Franklin letter and the Constitutional Convention. The sometimes unfriendly relationships continued to make unification of the colonies close to a necessity. Much of the original legislation emanating from Congress, after ratification of the Constitution, was directed at Indian affairs because of the potentially hostile tribes at the frontier, not because of admiration for the native peoples. In short, strengthening the central government would make it possible to deal with the "merciless Indian Savages" Thomas Jefferson had referred to in the Declaration of Independence ${ }^{25}$ - or the "savage tribes," Hamilton's term in The Federalist. ${ }^{26}$ (Would a rational new nation take its governing principles from merciless savages or savage tribes?)

Despite occasional intimations in the literature to the contrary, Franklin's statement about the Iroquois Confederacy included in the Parker letter-that the Confederacy "has subsisted ages, and appears indissoluble" - wasn't made at the 1754 Albany Congress. ${ }^{27}$ That congress is often cited as the start of the serious push for confederation, and it was attended by many representatives of Indian nations, particularly from the Iroquois Confederacy. ${ }^{28}$ At the Albany Congress, Franklin did

$23 \quad$ Id. at 117.

24 Franklin noted that Indians had fighting skills that could have been invaluable to the colonists in the right circumstances:

Every Indian is a Hunter; and as their Manner of making War, viz. by Skulking, Surprizing and Killing particular Persons and Families, is just the same as their Manner of Hunting, only changing the Object, Every Indian is a disciplin'd Soldier. Soldiers of this Kind are always wanted in the Colonies in an Indian War; for the European Military Discipline is of little Use in these Woods.

Id. at 120.

25 See The Declaration of Independence para. 20 (1776) ("He [the king] has . . . endeavoured to bring on the Inhabitants of the Frontiers, the merciless Indian Savages, whose known Rule of Warfare, is an undistinguished Destruction, of all Ages, Sexes and Conditions.").

26 See The Federalist No. 24, at 61 (Alexander Hamilton) (Clinton Rossiter ed., 1961):

The savage tribes on our Western frontier ought to be regarded as our natural enemies .... Previous to the Revolution, and ever since the peace, there has been a constant necessity for keeping small Garrisons on our Western frontier. No person can doubt that these will continue to be indispensable, if it should only be against the ravages and depredations of the Indians.

27 See William N. Fenton, The Great Law and the Longhouse: A Political History of THE IROQuoIs CONFEDERACy 471 (1998).

28 Indian nations, particularly the Iroquois, were represented in Albany, although not in the numbers that might have been expected. See Timothy J. Shannon, Indians and Colonists 
express support for unification of a sort, as he had in the letter to Parker. But, as the title of the Kennedy pamphlet suggests, it was the "British interest" that was to be protected-unification within the British Empire, not the creation of a new united states. ${ }^{29}$ Historian Timothy Shannon has explained, "Identifying Franklin or any other supporter of the Albany Plan as an embryonic American patriot in 1754 is misguided; quite to the contrary, his primary objective was to place the Crown's American subjects on a more equal footing with those of Britain." ${ }^{30}$

Most important, the Franklin quotation in its unedited form-decidedly not the form intimated by footnote 7-doesn't come close to supporting the influence thesis:

It would be a very strange Thing if six Nations of ignorant Savages should be capable of forming a Scheme for such an Union, and be able to execute it in such a Manner, as that is has subsisted Ages, and appears indissoluble; and yet that a like Union should be impracticable for ten or a Dozen English colonies. ${ }^{31}$

That's hardly a positive statement about Iroquois principles. ${ }^{32}$ Yes, Franklin urged consolidation of the colonies, but his urging was in the nature of "if even the

at the Crossroads of Empire: The Albany Congress of 1754, at 127-30 (2000); id. at 199-200:

Franklin, on his way downriver [after the congress], wrote to [Cadwallader] Colden complaining of the delay caused by the Indians, when "after all nothing of much Importance was transacted with them." ... In light of Franklin's dismissive remark about the Indians' role in the congress, the notion of an Iroquois influence on the Albany Plan seems farfetched indeed.

29 See SHAnNon, supra note 28, at 63-76. Franklin in the Parker letter had proposed a "voluntary Union entered into by the Colonies themselves," as "preferable to one imposed by Parliament," Franklin Letter, supra note 14, at 118, but by the time of the Albany Congress he was hoping that Parliament would act. See Editor's Note 1, id. at 118.

30 ShanNon, supra note 28, at 198; see also FENTON, supra note 27, at 471 (noting that Indian participants at the Congress were more interested in promoting grievances than in providing a model for the new United States).

31 Franklin Letter, supra note 14, at 118-19.

32 See Shannon, supra note 28, at 103 ("When Franklin referred to 'Six Nations of Ignorant Savages,' he was using the Iroquois as a negative example to illustrate the colonists' failure to recognize their own common interests."); see also FENTON, supra note 27, at 471:

This bit of satire on Franklin's contemporaries has of late inspired proponents of the idea that the writers of the United States Constitution derived its structure and separation of powers from the Iroquois Confederacy, a doctrine for which supporting evidence has escaped responsible scholars. None of Franklin's contemporaries . . . left an account of the internal workings of the confederacy for James Madison to follow. Not until the middle of the nineteenth century did such appear in Lewis Henry Morgan's classic League of the Ho-de-no-sau-nee, or Iroquois (1851). Like much of what else is advanced today as politically correct, this spurious doctrine represents invented tradition . . . .

See also Tooker, supra note 20, at 311-12 (noting that it was not until publication of Morgan's 1851 work that information about the Iroquois was widely available). Tooker is doubtful the founders would have found much of the Great Law of Peace acceptable (if they had known about it to begin with). Id. 
ignorant Iroquois can do it, of course we can." In any event, it's hard to imagine confederation wouldn't soon have been on the table for consideration regardless of what any colonist thought about the Iroquois Confederacy.

\section{B. The Concurrent Resolution}

Footnote 7 quoted the Franklin letter in edited form and out of context. That also happened with the congressional committees considering what became House Concurrent Resolution 331, passed by Congress in $1988^{33}$ and also cited and quoted, for some unfathomable reason, in footnote 7. (The resolution was cited as "recognizing the influence of "the Iroquois Confederacy and other Indian Nations [on] the formation and development of the United States." "'34) The House Committee on Interior and Insular Affairs, in reporting on the draft Concurrent Resolution on October 3, 1988, shortly before the resolution was adopted, wrote:

[T] he incorporation of such concepts as freedom of speech, the separation of powers in government and the balance of power within government so impressed Benjamin Franklin that he challenged the colonists to create a similar united government when he stated: "It would be a strange thing if the Six Nations Iroquois Confederacy $* * *$ should be capable of forming $* * *$ such a union $* * *$ and yet a like union should be impracticable for $* * *$ a dozen English colonies." ${ }^{35}$

But Franklin mentioned none of those concepts (freedom of speech, etc.) in his letter to Parker - that wasn't the reason for the letter - and the strategically placed asterisks turned the language quoted from the letter upside down. ${ }^{36}$ I'd like to be able to assume that dishonesty wasn't involved in editing the language for inclusion in the House Report, just a high level of enthusiasm about a fashionable idea. But the resulting misrepresentation was so great that such an assumption is hard to make.

That's one of the reasons the citation to House Concurrent Resolution 331 in footnote 7 was bizarre. In that resolution, as noted, Congress had "recogniz[ed] the influence of 'the Iroquois Confederacy and other Indian Nations [on] the formation and development of the United States." "'37 The resolution was actually even more specific, stating that "the confederation of the original Thirteen Colonies into one republic was influenced by the political system developed by the Iroquois Confederacy as were many of the democratic principles which were incorporated into the Constitution itself." ${ }^{\prime 3}$ As if that statement of the influence thesis weren't strong enough on its own, the resolution "acknowledge[d] the contribution of

33 H.R. Con. Res. 331, 102 Stat. 4932 (1988).

34 Developments, at 1710 n.7 (quoting resolution (1) in H.R. Con. Res. 331, supra note 33). The resolution uses "to" rather than "on."

35 H.R. Rep. No. 100-1031, at 2 (Comm. Print Oct. 3, 1988).

36 Cf. supra text accompanying note 31 .

37 Developments, at 1710 n.7 (quoting resolution (1) in H.R. Con. Res. 331, supra note 33).

38 H.R. Con. Res. 331, supra note 33, Preamble. 
the Iroquois Confederacy of Nations to the development of the United States Constitution," and noted that "the original framers of the Constitution, including, most notably, George Washington and Benjamin Franklin, are known to have greatly admired the concepts of the Six Nations of the Iroquois Confederacy." ${ }^{39}$ That's piling on - making basically the same point over and over.

So the drafters of the resolution left no doubt about their overblown point. But I have no idea why anyone, especially the Harvard Law Review, would quote language from a congressional resolution as support for a historical proposition. Where's the evidence, for example, about the views of Franklin and Washington? ${ }^{40}$ You might cite a resolution to show what members of Congress thought at the time, I guess, but even that's a stretch. Most feel-good congressional resolutions are routinely adopted, without deliberation.

This particular resolution did get limited attention in Congress. A Senate version had been introduced on September 16, 1987, ${ }^{41}$ and, on December 2, 1987, the Senate Select Committee on Indian Affairs held a hearing in the morning on the resolution, with the testimony and submitted statements coming almost entirely from proponents of the influence thesis. ${ }^{42}$

The draft language of the resolution, at the time of that hearing, had provided that the confederation of the thirteen colonies "was explicitly modeled upon the Iroquois Confederacy." 43 That's the influence thesis in its most robust, and ridiculous, form - that the U.S. Constitution had its origins in the Iroquois Great Law of Peace. ${ }^{44}$

Somebody must have realized that this was going way too far, however, despite testimony that would have supported such language. The Committee changed the wording before approving the resolution. "[E]xplicitly modeled upon the Iroquois Confederacy" was toned down to "influenced by the political system developed

$39 \quad$ Id.

40 Washington and Franklin were important presences at the Convention-Washington a brooding omnipresence, the aged Franklin, at the end of the Convention, summing up what had happened and supporting the compromises made along the way — but neither played a significant role in the details of the final document. In any event, we know Franklin's views of the Iroquois Confederacy from the unedited version of the Parker letter discussed earlier.

Washington's views about the Iroquois Confederacy were no more positive. At a hearing on the resolution, see S. Hrg. 100-610, Iroquois Confederacy of Nations, Hearing on S. Con. Res. 76 Before the S. Select Comm. on Indian Affairs, 100th Cong. (Dec. 2, 1987), historian Donald Grinde provided "selected factual data" to support the influence thesis, including a quotation from a September 7, 1783, letter from Washington to James Duane: "I have been more in the way of learning the Sentimts. of the Six Nations than of any other Tribes of Indians." Reprinted in George Washington: Writings 535, 537 (John Rhodehamel ed., 1997), and quoted in S. Hrg. 100-610, supra, at 137. That sounds nice, but Washington wasn't "admir[ing] the concepts of the ... Iroquois Confederacy," as the resolution put it. He was writing about the possibility of war if attempts were made to displace the Six Nations. He was noting that he knew more about the possibility of their resistance to removal than he knew about how other tribes would react.

41 S. Con. Res. No. 76, introduced at 133 Cong. Rec. 24214, 24223 (Sept. 16, 1987).

42 See S. Hrg. 100-610, supra note 40.

43 S. Con. Res. No. 76, supra note 41.

44 See, e.g., Schaaf, supra note 18 (seeing all sorts of similarities between the two documents). 
by the Iroquois Confederacy." ${ }^{45}$ That was still pretty strong, though, and the report of the Senate Committee on the resolution, dated September 30, 1988, while noting the change and attributing it to the need to conform the language to that in the House version, ${ }^{46}$ held nothing back: "More than 200 years ago, the framers of the United States Constitution reviewed the principles of democracy and the democratic institutions of the Six Nations of the Iroquois Confederacy, and then drew from the Iroquois' experiences in constructing the United State's [sic] form of government." ${ }^{47}$ Evidence? None.

The change to the more temperate, but still over-the-top, language - the one significant change along the way in the legislative process ${ }^{48}$ - was apparently made because it was thought the original language wasn't "completely accurate." 49 Indeed. But the amended language, which was also contained in the original House version of the resolution, as introduced on July 11, 1988, by Representative Morris Udall, ${ }^{50}$ wasn't "completely accurate" either.

The preposterous resolution nevertheless breezed through Congress, quickly and with almost no resistance. A perfunctory "debate" about the resolution took place on the House floor on October 3, 1988. ${ }^{51}$ The resolution passed the House on October 4, 1988, with 408 yea votes and only 8 nays, ${ }^{52}$ and the Senate passed it with unanimous consent, on October 21,1988 , the last day of the session. ${ }^{53}$

45 S. Rep. No. 100-565, at 3 (Comm. Print Sept. 30, 1988).

46 Id. at 1 (noting the amendment); id. at 3 ("The amendment adopted in Committee to the third clause of the resolution will conform the language of Senate Concurrent Resolution 76 to the language of House Concurrent Resolution 331 [see infra text accompanying note 52] which is pending in the House and is otherwise identical to Senate Concurrent Resolution 76.").

$47 \quad I d$. at 3.

48 See S. Rep. No. 100-565, supra note 45, at 1.

49 See Marybeth Farrell, Untitled (Sept. 30, 1988) (State News Service dispatch, dateline Washington), available on LEXIS (quoting Alex Skibine, with name misspelled, deputy counsel for Indian Affairs for House Interior and Insular Affairs Committee). Skibine added that the language ultimately adopted was "general enough that people with different interpretations of history could have enough room for discussion." Id. Discussion yes, agreement no.

Some proponents of the influence thesis have written that the Senate voted to adopt the resolution in its original form, with the "explicitly modeled" language, and they've given great weight to that mythical adoption. See, e.g., Gregory Schaaf, Indian Great Law of Peace (Kaianerekowa) [hereinafter Schaaf, Encyclopedia], entry in 2 ENCYCLOPEDIA OF American Indian History 410, 412 (Bruce E. Johansen \& Barry M. Pritzker eds., 2008) (stating that the Senate voted in favor of the original language and that "[ $\mathrm{f}$ ] history, Congress officially recognized that the U.S. government was 'explicitly modeled' after the Iroquois Confederacy"). In support of that made-up position, Schaaf cited to the Congressional Record for the day the Senate version of the resolution was introduced (September 16, 1987), not the date the Senate voted, over a year later, after the language had been changed. The Senate website affirms, in response to a frequently asked question, that the Senate didn't take the vote Schaaf claimed it had. See http://www.sente.gove/ reference/common/faq/Iroquois_Constitution.shtml ("The answer is no" to the question, "Is it true that ... [t] he Senate passed a resolution on September 16, 1787[,] stating that the U.S. Constitution was explicitly modeled upon the Iroquois Constitution?").

$50 \quad$ See 134 Cong. Rec. 17433 (July 11, 1988).

$51 \quad$ See 134 Cong. Rec. 27948 (Oct. 3, 1988).

52 See 134 Cong. Rec. 28140 (Oct. 4, 1988).

53 See 134 Cong. Rec. 32467 (Oct. 21, 1988). 
To explain how this happened, a congressional aide was quoted as saying, "I'll be honest with you, a commemorative resolution is not one of the highest priorities of the 100th Congress." 54 (As a news story noted, "Aides to Senate sponsors . . . admitted the resolution may have escaped close scrutiny because of Congress' heavy agenda before adjourning in time for the November elections." ${ }^{55}$ ) One thing can be said for sure: House Concurrent Resolution 331 wasn't the result of informed deliberation by anyone-members of Congress or trained historians. Historian Peter Axtell complained that most historians were unaware of the existence of the draft resolution until it was too late to resist enactment. ${ }^{56}$

And resistance would have occurred. The late Francis Jennings, director emeritus of the D'Arcy McNickle Center for the History of the American Indian at the Newberry Library in Chicago, was quoted as saying, about the amended (that is, relatively temperate) version of the resolution, "I don't know how [the committees] let it get through. ... . It destroys my faith in the historical literacy of the Senate." 57 Axtell similarly objected that "[t]he Confederacy has hoodwinked Congress into getting that resolution passed." 58

On the same day the resolution was approved by the Senate, Congress passed resolutions indicating support for the National Purple Heart Museum ${ }^{59}$ and the United States Senate Historical Almanac. ${ }^{60}$ With such important business to transact - excuse the sarcasm - one can see why members of Congress weren't focused on the contents of House Concurrent Resolution 331. It's harder to see why members of the Harvard Law Review weren't.

\section{Footnote 9}

Footnote 9 in the Developments chapter added more wishful thinking. In support of a textual reference to the "long history of tribal self-government," 61 that note said, "The Great Law of Peace, the constitution of the Iroquois Confederacy, was drafted [sic] perhaps as early as August of $1142 . "{ }^{\prime 2}$ The cited authority for that point was an essay by Barbara Mann in the Encyclopedia of the Haudenosaunee (Iroquois

\footnotetext{
$54 \quad$ Farrell, supra note 49 (quoting congressional aide).

Id.

Id.

Quoted in id.; see also Fenton, supra note 27, at 471; Payne, supra note 6; Philip A. Levy, Exemplars of Taking Liberties: The Iroquois Influence Thesis and the Problem of Evidence, 53 WM. \& MARY Q. 588, 603-04 (1996) (characterizing Exemplar of Liberty, supra note 5, as "a crazy quilt of inaccurate assessments, free-floating speculations, incorrect or disembodied quotations, and thesis-driven conclusions"). But see Donald A. Grinde, Jr. \& Bruce E. Johansen, Sauce for the Goose: Demand and Definitions for "Proof" Regarding the Iroquois and Democracy, 53 WM. \& MARY Q. 621 (1996) (responding to criticism of their work).

58 Quoted in Marybeth Farrell, Untitled (Sept. 22, 1988) (State News Service dispatch, dateline Washington), available on LEXIS.

59 See H.R. Con. Res. 126, 102 Stat. 4932 (1988).

$60 \quad$ See S. Con. Res. 146, 102 Stat. 4933 (1988).

${ }_{61}$ Developments, at 1710 n.9.

62 Id.
} 
Confederacy), a volume that bought into the influence thesis ${ }^{63}$ How do we know that August 1142-what a nice sense of precision! - was "perhaps" a key date? According to the Encyclopedia, it's because of oral tradition ${ }^{64}$-you know, passing stories from one generation to the next, with embellishment inevitably occurring along the way ${ }^{65}$ - and tying certain events to solar eclipses, particularly one that occurred on August 31, 1142 (more precision!): “The Keepers speak of a Black Sun (total eclipse) that occurred immediately before the league was founded." ${ }_{66}$

To be fair to the Encyclopedia folks, that volume didn't say anything about "drafting" the Great Law of Peace. The word "drafting" came from footnote 9. I'm not sure what the Harvard Law Review authors and editors thought "drafting" would mean in this context-wampum, perhaps, but translations of wampum weren't available to the American founders. What were the Harvard Law Review people thinking in letting this stuff appear in their pages?

Footnote 9 is perversely interesting also because, in demonstrating the "long history of tribal self-government," and after the reference to the year 1142, the authors wrote that "[o]ther tribes, like the Cherokee and Chickasaw, passed constitutions of their own in the early to mid-nineteenth centuries. . . . These constitutions [of the Cherokee, the Chickasaw, and the Choctaw Nations] often were the products of constitutional conventions and extensive thought by the tribes that drafted them." ${ }^{67}$ That may be, but it's a big jump from 1142 to the nineteenth century.

If we were to conclude that some connection exists between the U.S. Constitution and tribal governing documents, and those tribal documents were drafted after the American founding, what is the chain of causation likely to have been? For that matter, the Great Law of Peace was reduced to writing not in 1142 or any other eclipse year, ${ }^{68}$ but in the late nineteenth century. ${ }^{69}$ Again, if similarities are found between the written Great Law of Peace and the Constitution - the similarities

63 Barbara A. Mann, Haudensee (Iroquois) League, origin date, entry in ENCYCLOPEDIA OF the Haudenosaunee (Iroquois Confederacy) 152 (Bruce Elliott Johansen \& Barbara Alice Mann eds., 2000).

${ }^{64}$ For example, the late Mohawk Chief Jake Swamp was quoted as saying, in a 1983 conversation, that "[o]ur Iroquois chiefs and clan mothers have long said that the Great Law of Peace served as a model for the U.S. Constitution. We know that our ancestors met personally with Benjamin Franklin, Thomas Jefferson, James Madison and others involved in drafting the U.S. Constitution." Quoted in Schaaf, Encyclopedia, supra note 49, at 412. Well, that settles it then. (Would it be impolite to note that Jefferson didn't attend the Constitutional Convention, and Franklin wasn't involved in drafting constitutional language?)

65 Think John Smith and Pocahontas, Washington and the cherry tree, Eliot Ness and the Untouchables.

66 Mann, supra note 63, at 152. Mann notes, to her credit, that solar eclipses visible in the relevant part of North America also occurred in 1451, 1550, and 1654. Id. Even if the occurrence of an eclipse were really important in dating the Great Law of Peace, 1142 thus isn't the only possibility.

67 Developments, at 1710 n.9.

68 See supra note 66.

69 See Farrell, supra note 49 (quoting Ives Goddard, curator of Anthropology at the Smithsonian: "[T]he Great Law Documents ... . don't date to nearly a hundred years after the Constitution. The possibility has to be considered that the influence went the other way."); supra note 32 (noting significance of 1851 publication of Lewis Morgan's treatise). 
seem to me minimal, but others have more imagination - which "document" would have been the influencer and which the influenced?

\section{A Few Additional Thoughts on the Influence Thesis}

I've written before about the imaginary connection between the Great Law of Peace and the U.S. Constitution, ${ }^{70}$ and I've been criticized by tribal officials for not understanding the concept of "cultural diffusion"- that, "[w]henever two cultures come into contact, an immense amount of information changes hands immediately." ${ }^{171}$ The idea, I guess, is that the founders adopted Iroquois principles, with a high level of specificity, without realizing where those principles came from. That's close to a world record for implausibility.

It's also been said that we shouldn't be surprised when little or no documentation can be found to support the influence thesis: the events occurred over 200 years ago, hence the need to rely on oral traditions. ${ }^{72}$ But the founding era is well documented. Not every piece of writing is trustworthy, of course, but if the founders were relying on ideas of the Iroquois Confederacy (or of any other American Indian nation), it's hard to imagine we couldn't find mention of that somewhere - in Madison's notes from the Constitutional Convention, in reports of debates in the state ratifying conventions, in the Federalist Papers, in newspapers or other contemporaneous tracts - something somewhere.

The rebuttal might be that no written record exists because the delegates to the Constitutional Convention wanted to keep the Indian influence secret. Most of them wanted ratification to occur, of course, and the document was doomed if it was understood to have been derived from the Iroquois. But that hypothesis presupposes a conspiracy of silence of breathtaking scope. Besides, if the purported source of constitutional principles would have caused ratification problems, why wouldn't the Anti-Federalists, some of whom were at the Convention, have noted this connection in their voluminous writings? If you're looking for ways to defeat the Constitution, why wouldn't you bring out the big guns - if the big guns exist? Historian Shannon sees the relationship between the founding documents and the Iroquois in a much more convincing way:

The Articles of Confederation and the United States Constitution . . . were decidedly anti-Iroquois in their ramifications: they assumed for the federal government exclusive powers in Indian affairs that made it impossible to turn back the clock and reinstitute the local diplomacy that had once sustained the council fire in Albany. . . . From the Indian perspective, the true legacy of the Albany Congress was the increasing

See Jensen, supra note 18.

71 Introduction, in Exiled in the Land of the Free: Democracy, Indian Nations, and the U.S. Constitution 9 (Oren R. Lyons \& Jon C. Mohawk eds., 1992).

72 See, e.g., Charles Radlauer, The League of the Iroquois: From Constitution to Sovereignty, 13 St. Thomas L. Rev. 341, 352 (2000) (ridiculing "Jensen's insistence upon written documentation two centuries after the fact"). I plead guilty. 
use of federal power to cement their dependency and removal in the new American republic. ${ }^{73}$

I'll make one concession. The influence thesis is indefensible, but it's not only crazies who have supported one version or another of the thesis over the years. For example, the legendary Felix S. Cohen, usually given credit for creating the field of American Indian law in his masterful Handbook of Federal Indian Law, ${ }^{74}$ could also engage in hyperbole:

For it is out of a rich Indian democratic tradition that the distinctive political ideals of American life emerged. Universal suffrage for women as well as for men, the pattern of states within a state that we call federalism, the habit of treating chiefs as servants of the people instead of as their masters, the insistence that the community must respect the diversity of men and the diversity of their dreams - all these things were part of the American way of life before Columbus landed. ${ }^{75}$

Cohen went so far as to say that "what is distinctive about America is Indian, through and through, ${ }^{, 76}$ a striking conception of American exceptionalism.

Cohen was a serious scholar, but he wasn't above romanticizing the past with the goal of improving the future for the American Indian nations. How could he have known most of that pre-1492 history, including the "diversity of their dreams"? More oral traditions, I guess. And, although it isn't politically correct to say so, wars between American Indian tribes weren't unheard of over the centuries.$^{77}$ Diversity of men and dreams can go only so far.

\section{CONCLUSION}

The influence thesis shouldn't be taken seriously, in the pages of the Harvard Law Review or anywhere else, but that conclusion isn't intended to denigrate American Indian nations. In fact, if one has the interests of those nations in mind, it's risky to act as though a theory that is at best suspect and at worst nonsense is important to their status. American Indian policy doesn't depend on the validity of an ahistorical thesis.

\footnotetext{
SHANNON, supra note 28, at 239.
}

74 Felix S. Cohen, Handbook of Federal Indian Law (1941). Since the time of the founding, doctrine was plentiful - treaties with the tribes, what is now title 25 of the United States Code, and judicial decisions. Cohen created the field by pulling that material together while he was serving in the Office of the Solicitor in the Department of the Interior.

75 Felix S. Cohen, Americanizing the White Man, Am. Scholar, Spring 1952, at 171, 17879 , reprinted in The Legal Conscience: Selected Papers of Felix S. Cohen, at 315, 317 (Lucy Kramer Cohen ed., 1970).

76 Cohen, supra note 75, at 178, reprinted in LeGal ConsCIENCE, supra note 75, at 316.

${ }_{77}$ The Iroquois were particularly ferocious in war. See Jensen, supra note 18, at 299. 
Almost thirty years ago, ethnographer Elizabeth Tooker noted that the influence thesis - under which white man's law is treated, in its fundamentals, as equivalent to traditional tribal law-actually denies the distinctiveness of American Indians:

Some recent interpretations of Indian cultures and history have turned this "negative prototype" on its head, asserting that, indeed, Indians did hold white ideals and ... even that whites got them from the Indian. But as laudable as this might at first glance seem, such a positive stereotype exhibits not only as little fundamental understanding and appreciation of Indian cultures as a negative one, but also little understanding of Western culture. We owe our fellow residents on the continent better. ${ }^{78}$

In seeking to emphasize the importance and distinctiveness of American Indian nations, proponents of the influence thesis may be doing exactly the opposite.

In any event, nothing is gained by endorsing the influence thesis, and what is lost is something we should all care about: the truth.

\section{Appendix: The Incongruity at the Core of the DeVElopments CHAPTER}

The body of this article vents about the influence thesis. For anyone interested, I want to make a substantive criticism of the Developments chapter from the Harvard Law Review - in particular, the recommendation that tribal governments be given primary responsibility for interpreting the Indian Civil Rights Act, even in habeas cases.

It makes sense to defer to tribal governments on many issues, of course, but civil rights isn't necessarily one of them. Civil rights statutes are intended to protect individuals, and ICRA was intended to limit the powers of American Indian nations over tribal members. ${ }^{79}$ Deferring to a government's interpretation of a statute intended to constrain that government isn't the intuitively right way to proceed. After all, during the civil rights era, when ICRA was enacted, southern officials claimed that state governments were the best judges of how their societies should be structured. But that system wasn't working well-to put it mildly.

I don't mean to liken today's tribal governments to Jim Crow-era state governments. But there's no reason to think tribal governments are inherently noble and unlikely therefore ever to engage in abusive behavior; human nature is human nature. That's why ICRA came into being: to protect tribal

\footnotetext{
78 Tooker, supra note 20, at 327.

79 The second section of ICRA, codified at 25 U.S.C. $\S 1302$, is titled "Constitutional rights." Subsection (a) provides that "[n]o Indian tribe in exercising powers of self-government shall" engage in any of ten listed behaviors-generally a statutory application of most bill of rights provisions to American Indian tribes. The constitutional limitations would otherwise not be applicable.
} 
members-American citizens, after all-from overreaching by their own tribal governments. ${ }^{80}$

That protection seems to require scrutiny of questionable governmental behavior by someone outside the tribal system. For the most part, however, ICRA has turned out to be a statement of aspirations rather than an enforceable legal document. The Supreme Court's 1978 decision in Santa Clara Pueblov. Martine $z^{81}$ — holding that, under ICRA, aggrieved tribal members have no recourse in federal court against their tribal governments, except in habeas cases-reduced the potential impact of ICRA dramatically. ${ }^{82}$

If the only forum available to a tribal member who believes his civil rights have been abridged by a tribal government is tribal court — and that would be the result, even in habeas cases, of the Developments recommendations - the protections of ICRA aren't worth much to that member. A tribal court, if it exists at all, ${ }^{83}$ isn't necessarily separate from other governmental branches - if other branches exist. (Tribes aren't required to have governments with separation of powers, and a tribal court therefore doesn't necessarily represent an independent judiciary.) The aggrieved tribal member's claim may thus be adjudicated by those, or the friends of those, accused of violating ICRA. The likely result is obvious.

Any discussion of ICRA's merits must be informed by a fundamental principle: neither states' rights nor tribal rights should trump individual rights.

80 Maybe other reasons were involved as well, but protecting individual rights was the stated motivation.

81436 U.S. 49 (1978).

82 The Court in Santa Clara Pueblo merely held that Congress hadn't made it explicit that federal courts should have jurisdiction over ICRA matters, except for habeas proceedings, where federal judicial review is provided for. See supra note 4. Without clear authorization, the Court said it wasn't going to infer federal jurisdiction. It's true that Congress wasn't explicit, but it would have been easy, I think, to infer that Congress intended that result. What otherwise was the point of ICRA? (On the other hand, in the intervening 38 years, Congress hasn't stepped in to reverse the effects of Santa Clara.)

83 The Developments chapter recognized that not all tribes have courts and suggests how that problem can be addressed for ICRA purposes. See Developments, at 1728. 